\title{
MODEL OF THE SCIENTIFIC AND TECHNICAL Creation Processes
}

\author{
GHERGHEL, N.
}

Abstract: The chapter presents, describes and exemplifies a systemic graphic model as well as a diagram or a graph of the scientific and technical creation processes, respectively. The inputs are represented by the inspiration sources while the outputs are represented by the new solutions, variants and ideas. The creation processes themselves consist in the application of the creation methods, techniques, approaches and procedures. Also is presented an example for application of the model of the creation processes for presentation "the standard specialized fund of creation ideas" - "the standard specialized individual fund of creation ideas for the subfield of the simple bearers from the structure of the technological device".

Key words: process; idea; creation; creation process; model; graph; graphic model; systemic model
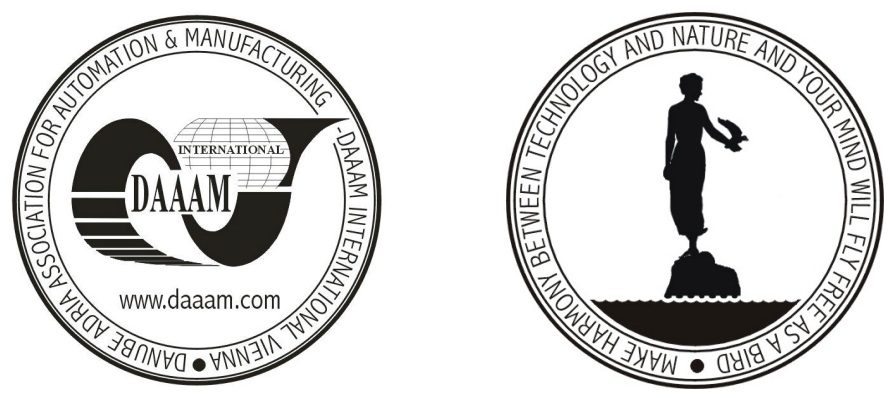

Authors' data: PhD Gherghel N.[icolae], Tech. U. "Gh. Asachi” Iassy, Romania, ngherghel@athena.mt.tuiasi.ro

This Publication has to be referred as: Gherghel, N. (2006). Model of the Scientific and Technical Creation Processes, Chapter 19 in DAAAM International Scientific Book 2006, B. Katalinic (Ed.), Published by DAAAM International, ISBN 3-901509-47-X, ISSN 1726-9687, Vienna, Austria

DOI: $10.2507 /$ daaam.scibook.2006.19 